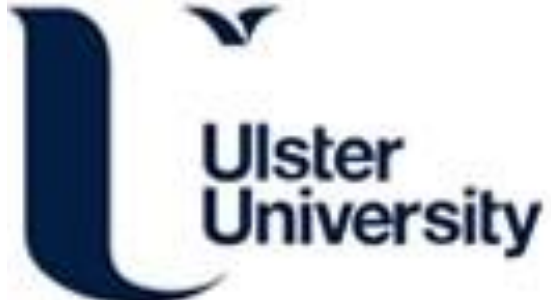

\section{Use and Perceptions of E-books by Academic Staff in Further Education}

Mulholland, E., \& Bates, J. (2014). Use and Perceptions of E-books by Academic Staff in Further Education. Journal of Academic Librarianship, 40(5), 492-499. https://doi.org/10.1016/j.acalib.2014.05.018

Link to publication record in Ulster University Research Portal

\section{Published in:}

Journal of Academic Librarianship

Publication Status:

Published (in print/issue): 30/09/2014

DOI:

10.1016/j.acalib.2014.05.018

\section{Document Version}

Author Accepted version

\section{General rights}

Copyright for the publications made accessible via Ulster University's Research Portal is retained by the author(s) and / or other copyright owners and it is a condition of accessing these publications that users recognise and abide by the legal requirements associated with these rights.

\section{Take down policy}

The Research Portal is Ulster University's institutional repository that provides access to Ulster's research outputs. Every effort has been made to ensure that content in the Research Portal does not infringe any person's rights, or applicable UK laws. If you discover content in the Research Portal that you believe breaches copyright or violates any law, please contact pure-support@ulster.ac.uk. 


\title{
Use and Perceptions of E-books by Academic Staff in Further Education
}

Elaine Mulholland

Librarian, St. Mary's University College, 191 Falls Rd., Belfast, BT12 6FE, Northern Ireland. Email: e.mulholland@stmarys-belfast.ac.uk

Dr Jessica Bates

Course Director for Library and Information Management, School of Education, University of Ulster, Coleraine Campus, BT52 1SA, Northern Ireland. Email: j.bates@ulster.ac.uk

\begin{abstract}
This article reports on a study of the awareness, perceptions and use of e-books by academic staff in Further Education (FE) colleges throughout Northern Ireland (NI). It is the first comprehensive study of e-book use by FE faculty in NI and fills a significant gap in the research literature on e-books in education, which has tended to focus on Higher Education and the university setting. Data was collected through an online survey which was distributed to FE faculty across NI. The findings show that although FE academic staff are receptive to e-books and welcome them as a resource, poor reading experience and lack of awareness of relevant titles have had an impact. In particular, the research found that $40 \%$ of academic staff, in post less than five years, had not used e-books. Greater availability of titles, promotion, and better integration within teaching and learning emerge as key requisites for effective service delivery and enhancement of e-books within FE, as does the need for better targeted instruction and training aimed at academic staff. Understanding patrons' views, awareness, needs, habits and expectations in relation to e-books is crucial to help direct collection content while budgets remain tight and physical space limited.
\end{abstract}

\section{Keywords}

Academic staff, e-books, Further Education; Northern Ireland; perceptions and use, United Kingdom. 


\section{Introduction}

Technological innovations have driven libraries in recent years and e-books have received an increasing amount of attention and compelled many libraries to review their collections and how they provide information services. In 2009, e-books were a relatively new concept within Further Education (FE) ${ }^{1}$. In the UK however, Jisc Collections has played a major role by developing an e-book collection specifically for $\mathrm{FE}^{2}$. It had become clear there was a demand for vocation and skilled based e-textbook titles. By providing FE colleges with a critical mass of e-books related to their courses, Jisc Collections was assisting the colleges develop their e-book collections for academic staff and students. FE colleges throughout the UK now have an extensive collection of educational e-books across most disciplines, due to the efforts of Jisc Collections.

In Northern Ireland (NI) ${ }^{3}$, prior to the development of the Jisc Collections e-book initiative, the majority of FE colleges ${ }^{4}$ had limited or little access to e-book collections. Although most

\footnotetext{
${ }^{1}$ The Department for Employment and Learning (DEL) provides useful background information on the structure of the FE sector in Northern Ireland. According to their website, DEL is responsible for the policy, strategic development and financing of the statutory FE sector in N. Ireland. FE colleges are free-standing incorporated bodies. Management responsibility lies with each individual college's governing body and Colleges Northern Ireland (CNI) acts as the representative body for FE in N. Ireland (http://www.delni.gov.uk/index/further-andhigher-education/further-education/background-to-the-further-education-sector.htm).

In the USA, the equivalent colleges are usually called Continuing Education or Community Colleges; while in Australia, they are referred to as Technical and Further Education or TAFE.

The FE Colleges in Northern Ireland are the main providers of vocational and technical education and training. College provision range from GCSEs and A levels to BTECs, HNCs, Foundation Degrees, Apprenticeships, Degrees (HE) and other specific training programmes.

${ }^{2}$ Historically, JISC stood for Joint Information Systems Committee however the company is now known as Jisc, and Jisc Collections is part of this. According to the Jisc website (http://jisc.ac.uk/about), they are a registered charity that champions the use of digital technologies in UK education and research. Over $80 \%$ of JISC funding comes from the UK HE and FE funding bodies, with additional support coming from higher education institutions. Approximately 3000 e-book titles are available free of charge to every FE college in the UK, via ebrary. These e-books are available to support taught courses for both FE students and lecturers and were chosen through extensive consultation between academic staff, library staff and Jisc Collections. For information about their e-books for FE service see: http://www.jisc.ac.uk/e-books-for-fe.

${ }^{3}$ Northern Ireland is made up of six counties in the north east of the island of Ireland and is a semi-autonomous part of the United Kingdom (Source: http://news.bbc.co.uk/1/hi/world/europe/country_profiles/4172307.stm).

${ }^{4}$ The NI FE sector comprises of six colleges (Belfast Metropolitan College; Northern Regional College; North West Regional College; Southern Regional College; South Eastern Regional College; and South West College), spread across $40+$ campus sites.
} 
had adopted e-journal and e-database resources, e-books had not significantly infiltrated FE library collections.

This study, which was undertaken in $2011^{5}$, focuses on the experiences and perceptions of staff, rather than students, because overall, fewer studies have centred on the academic staff perspective and experience. In FE, e-books have been relatively slow to take off and it is important to have academic staff support, as an influencing factor, to encourage usage amongst their students. Furthermore, library budgets are directly driven by the pedagogical needs of academic staff in FE. Given the potential of e-books to enhance the FE teaching and learning experience, this research is considered to be timely and relevant and provides the foundations upon which to build more investigative work.

The objectives of the research were to:

- Identify the awareness and use / non-use of e-books amongst academic staff in FE in N. Ireland;

- Explore general attitudes, perceived advantages/disadvantages and barriers towards ebooks;

- Determine existing preferences for format type (print or e-book) and ascertain overall user satisfaction levels; and

- Attain an understanding of future trends for the effective promotion and marketing of e-books.

\section{Literature review}

In general, e-books are defined as digitised versions of paper-based books that can be delivered on a variety of electronic platforms, ranging from PCs to mobile devices. They can also be 'born digital'. E-books can have features that include: search options, cross reference functions, multimedia features and links within the text to external online sources (Rockinson-Szapkiw et al., 2013; Schomisch et al., 2013), and as Tucker (2012, p. 40) states, the e-book environment is 'rapidly and constantly evolving'. For a useful summary of current e-book formats and capabilities see JISC (2012). There are, however, crucial differences in e-book functionality for academic use, compared to non-scholarly use, with

\footnotetext{
${ }^{5}$ Further details can be found in Mulholland (2012).
} 
challenges in areas of licences and digital rights management (DRM) which have an impact on what users are permitted to do with the e-book (Walters, 2013a\&b).

There is a scarcity of studies that focus on the FE sector in relation to e-books in the UK or Ireland; instead the research has centred on the higher education (HE) experience ${ }^{6}$, hence this review draws on the literature from that domain. Although it should be noted that most of the Jisc reports reference both the FE and HE sectors with regard to e-books. Early studies provided an understanding of platform features, pedagogy and technology issues and reveal an unsatisfactory experience of e-books due to accessibility and unfamiliarity of e-book interfaces (Walton, 2007), whereas, later works discovered less apprehension with accessibility and more concern with relevant title coverage and availability of e-books for different subject areas (Briddon et al., 2009; de Oliveira, 2012; Nariani, 2009; Walton, 2013).

Ebrary's (2007) global HE faculty survey and some recent studies (for example, Pant and Jindal, 2013; Walters, 2013a,b,c) have found that e-journals are more popular than e-books due to their ease of use and access, and research in Ireland would indicate that e-books have not yet reached 'self-sustaining take off' (Smyth and Carlin, 2012, p. 176) or a 'tipping point' (Pan et al., 2009, p. S12). According to Nicholas and Lewis (2010): 'Enticing faculty to use e-textbooks is a challenge. ... This new media may have to prove its reliability and will have a learning curve'. Nevertheless, 'e-books have the potential to be even more significant for libraries and learners than e-journals' because of the enduring importance of textbooks for learning (Vasileiou et al., 2012, p. 217), and this is particularly true within the FE sector.

A Springer survey (2010), conducted at the University of Liverpool, showed more than $80 \%$ of respondents knew that they had access to e-books through the library and had actually used them. These findings reflect the way in which e-books have become an essential part of the

\footnotetext{
${ }^{6}$ Traditionally in the UK, FE colleges have offered vocational learning opportunities and HE universities academic qualification at graduate and postgraduate levels. However, the demarcation between FE and HE may seem to be blurring with an increasing number of FE institutions in the UK offering degree courses and an increasing number of HE institutions offering foundation and access courses which are pre-degree level.

Further education involves educational opportunities for those aged 16+, following on from secondary education, and can include both formal qualifications and short courses that are not certified. Higher education and learning usually takes place in a university setting and is for those aged 18+. Some of those students who complete an FE course of study will go on to a HE setting.
} 
information world within an education context. This growing trend echoes the 2008 JISC funded study on UK e-book usage and perceptions. It reported that $58 \%$ of teaching staff at over 120 participating universities were using e-books (JISC, 2008). Also, the majority of graduate students surveyed at York University, Toronto, were aware of e-books and $76 \%$ had used them (Nariani, 2009). Jisc Collections's (2009) final report of the National E-book Observatory Project agreed that e-books were now part of academia with $65 \%$ of teaching staff or students having used an e-book.

Findings show academic staff, like students, prefer to read a few pages, or surf through a chapter, rather than read the entire e-book (Lenares et al., 2013; McLure and Hoseth, 2012; Schomisch et al., 2013; Springer, 2010). The global survey conducted by ebrary (2007) found $79 \%$ of faculty stated they prefer traditional print format when reading a whole book, while Schomisch et al. (2013) in their study found that essential parts of e-books texts are printed out rather than read on screen.

While $36 \%$ of respondents in the ebrary (2007) survey identified that they did not use ebooks for teaching, the majority of faculty ( $81 \%$ of the ebrary study) had discovered eresources, including e-books from the library website and indicated the importance of information literacy and the promotion of e-books (Briddon et al., 2009; ebrary, 2007, 2012; Nariani, 2009). CIBER (2009a) however, found that university teaching staff are using more e-books and are starting to decrease the gap with their 'Net Generation' students. In their study of e-book use in the University of Dehli, Pant and Jindal (2013, p. 320) found that 45\% of faculty members used e-books (compared to $76 \%$ of students) and e-books indexed in the library catalogue were 'more likely to be used than e-books which are promoted through other media'.

Undoubtedly, users regard 'online access' as the key advantage of e-books (for example, see Jamali et al., 2009; Walters, 2013b; Walton, 2013). The consensus is that e-books offer convenience, the ability to view pages from on and off campus and 24/7 accessibility (for example, see Pant and Jindal, 2013). As Jisc Collections (2009) reports, almost a third of epages are viewed off campus and at all times of the day. E-books are used like reference books, to locate information and evidence rapidly, viewings are brief, and users do not normally read the entire book (Abdullah and Gibb, 2009; Lenares et al., 2013; Levine-Clark, 2007; Nariani, 2009; Walton, 2013). 
Although there is still debate over whether e-books will replace printed books, trends indicate libraries have been expanding their e-book acquisitions over the past few years. In the educational arena, JISC notes, core text e-books 'can be effectively used alongside rather than instead' of print (JISC, 2012, p. 27), they offer a 'safety valve' at times of peak demand, rather than a direct substitution for hard copy' (Jisc Collections, 2009, p. 5).

In the research literature, users are often asked to compare and contrast print with e-books and to assess the relative strengths and weaknesses of both. However, as O'Brien (2010) exclaimed, does one have to win? Should e-books be in direct competition with printed books? There is evidence that print books remain more popular than e-books with patrons for specific reasons (Daniel and Woody, 2013; Pant and Jindal, 2013; Walters, 2013b; Walton, 2013). Users have indicated that e-books are preferred for searches, information retrieval and convenience, but print books are preferred for extended reading (Cassidy et al., 2012; JISC, 2012; Walters, 2013b; Walton, 2013).

These conclusions are also reinforced by the responses to questions regarding the way students and faculty at the University of Liverpool (Springer, 2010) prefer to use and interact with various information sources. In terms of whether print books were favoured for reading a book continuously from cover to cover, respondents were clear in their preference for print books (see also, Pant and Jindal, 2013; and Schomisch et al., 2013), and when asked if a greater selection of e-books would be desirable, respondents also showed their support.

A survey conducted by Briddon et al. (2009) at the University of the West of England, found that overall, $32 \%$ of e-book users preferred print, $17 \%$ preferred e-books, while $51 \%$ had no preference. Shelburne's (2009) large scale study at Illinois University showed that users preferred e-books in terms of access, availability and storage, while print was first choice for 'ease and pleasure of reading' (Shelburne, 2009, p. 64). Faculty, as mentioned earlier, also prefer the manageability of the printed book. Jisc Collections (2009) and the ebrary (2007) surveys also support this view, with print being preferred for continuous extended reading, due in part to unfamiliarity with e-books, and lack of understanding of complex e-book interfaces. E-books are widely regarded as useful for retrieving information, but not particularly agreeable for reading ease (ebrary, 2012; Muir and Hawes, 2013). There is widespread agreement that e-books are complementary to collections and not a replacement 
of print books and they should co-exist due to the differential benefits of each format (CIBER, 2009b; Jisc Collections, 2009; JISC, 2012; Medeiros, 2010; Muir and Hawes, 2013; Vasileiou et al., 2012; Walton, 2013). As Soules (2009, p. 20) points out, 'the e-book will never be static, continually embracing new possibilities'.

E-books bring just as many challenges as benefits. Research conducted by Shelburne (2009), involving a large scale survey at Illinois University, is consistent with later research, such as Vasileiou et al.'s (2012) and Walton's (2013) findings on e-book usage. According to Shelburne (2009), 78\% of respondents used e-books for research purposes and stated that disadvantages towards them were technical. The perceived advantages and disadvantages of e-books, users' likes and dislikes, have been an on-going theme in the research (JISC, 2012; Muir and Hawes, 2013). Often the same features appear as both an advantage and disadvantage. Therefore, while online availability and search ability are noted as being an attractive feature of e-books for users in some studies (ebrary, 2012, Lenares et al., 2013; Muir and Hawes, 2013; Nicholas et al., 2008; Walters, 2013b), they are perceived as being problematic in others (Carlock and Perry, 2008; Walters, 2013b).

A survey by Briddon et al. (2009), at the University of West England, found $88 \%$ of their respondents indicated that 24/7 availability was the most appealing attraction of e-books. This was closely followed (77\%) by 'instant online access' (Briddon et al., 2009). At the University of Illinois, Shelburne (2009) describes similar findings, citing advantages as 'instant, desktop access (27\%), ability to keyword search (25\%), access from anywhere (17\%), portability (15\%) and environmentally better (7\%)'. Jisc Collections (2009), JISC (2012), Walters (2013b) and Walton (2013) back up these findings with accessibility being a reported advantage. As Schomisch et al. (2013, p. 391) sum up, 'from the users' perspective, immediate and ubiquitous access is already a strong argument in favour of e-books'.

A frequently noted disadvantage reported by users is the risk of eye-strain from reading content from a screen. Faculty members mentioned this in Nariani's (2009) study, while academic users also made this complaint in studies by Briddon et al. (2009), Shelburne (2009), and ebrary (2012). The other major disadvantages concerning e-books for both librarians and users are: technical issues, cost effectiveness, unavailability of core texts, nonstandardised platform interfaces, lack of awareness, navigation issues, problems with internet 
access, digital rights management and lack of consistency between vendors (ebrary, 2007, 2012; Walters, 2013a\&b).

A continuing concern that librarians and publishers face is the ability of users, or potential users, to find, utilise and retrieve e-books (Nariani, 2009; Roesnita and Zainab, 2005; Walters, 2013a\&c). It has been a frequent theme in e-book literature, as Walters declares: 'The effort required to find and use e-books is likely to be worthwhile only if patrons have a significant chance of finding e-book titles that meet their needs' (Walters, 2013a, p. 190). Even though library catalogues are often used as an access point to identify e-books, librarians must still effectively promote, deploy and market their e-book collections (Cassidy et al., 2012; de Oliveira, 2012; Muir and Hawes, 2013; Pant and Jindal, 2013; Vasileiou et al., 2012; Walters, 2013a). Librarians need to be pro-active and create improved outreach training for faculty (Vasileiou et al., 2012). In turn, faculty can further promote the use of ebooks to their students as their encouragement is often a prerequisite for motivating student use (Anuradha and Usha, 2006; Carlock and Perry, 2008; Rowlands et al., 2007), for example, Muir and Hawes (2013, p. 262) found that approximately half their student sample 'reported instruction from academic staff as a reason for using e-books'.

It is vital that software and mobile technology is compatible with library systems to ensure the information needs of the end user are met (JISC, 2012). Tonkin (2010) summarises the market trends and the technological aspects of e-book readers from a UK perspective. She explains there are obstacles to overcome if universities are to use e-readers for academic purposes. Primarily, vendor standards must be compatible, consistent and sustainable in terms of the digital rights management (Herlihy and Yi, 2010; JISC, 2012; Lenares et al., 2013; Schomisch et al., 2013; Walters, 2013a,b,c).

FE colleges are unique due to the diverse vocational courses and levels of study taught. Limited budgets and centralised senior management involved in the decision-making, can often create challenges. Courses tend to have essential 'set texts' chosen by lecturers or course teams, rather than supplementary or recommended reading. Together, these have implications for the licensing of e-books. The Jisc Collections (2010) FE report 'Migrating to e in UK Further Education' explains how crucial it is to have an uncomplicated, uniform and 'robust' delivery platform, 'whether browser or download based', that will provide extensive access for 'a diverse group of students at minimal cost' (Jisc Collections, 2010, p. 21). 
Several important themes emerge from this review of the literature. It is clear, that globally, e-books have become an integral part of libraries within educational establishments, and that librarians, publishers and platform providers still face challenges as e-books develop. Consequently, e-books give users flexibility and greater 'access to much more information than has been previously available and altering the manner in which patrons interact with materials' (Springer, 2010, p. 2).

While there is an emergent knowledge base relating to e-books in an academic context, the literature review also highlights an absence of data concerning the FE sector.

\section{Methodology}

Due to the widespread geographical location of the six Northern Ireland colleges (spread across 40+ campuses), an online survey (using Survey Monkey) was used to collect data. The survey began with demographic questions (faculty status; gender; number of years teaching), and subject and level taught, before moving on to focus on e-books. Questions were mainly multiple choice and scale questions, although there were opportunities for respondents to add their own comments for some of the questions.

The survey went live in April 2011, and librarians at each of the six FE colleges were asked to distribute an email to 'all academic staff', with information about the survey and a link to it. A copy of the survey questions can be found in the appendix.

A total of 229 completed questionnaires were received. The total number of faculty across the six colleges surveyed was approximately 3,277, i.e. academic staff from all subject disciplines, gender and academic status (associate, non-associate, full-time, part-time). Thus, the overall response rate for all six colleges equates to $7 \%$. However, as two of the colleges were only able to send out the survey to a limited number of academic staff, this resulted in a revised response rate of $10 \%$.

Descriptive statistics were used to analyse the data from the closed questions, and the responses to open-ended questions were examined for recurrent themes. 


\section{Findings}

In terms of the demographic profile of the survey respondents, the majority were females (70\%), which was higher than the gender breakdown of FE staff at 59\% female. Full-time staff accounted for $65 \%$ of respondents and $36 \%$ were part-time.

The modal category of number of years of teaching experience was more than 20 years (with $26 \%$ of respondents in this category), furthermore, $20 \%$ of respondents had less than five years' experience, so-there was a good range in terms of how long the respondents had been in post.

Table 1 below assessed the number of years in a teaching post with use of e-books. Surprisingly, a high proportion of non-users came from respondents new to teaching, that is, the $0-5$ year bracket. This distinctive finding highlights how those recently in post may be unaware of the library e-book collection available to them in their discipline area. It also reveals how important it is for library staff to promote e-books and to actively encourage and direct new faculty toward them.

Table 1: Number of years teaching and whether respondents had ever used an e-book

\begin{tabular}{l|l|l} 
& Yes & No \\
\hline $0-5$ years & $60 \%$ & $40 \%$ \\
\hline $6-10$ years & $67 \%$ & $33 \%$ \\
\hline $11-15$ years & $63 \%$ & $37 \%$ \\
\hline $16-20$ years & $68 \%$ & $32 \%$ \\
\hline More than 20 years & $59 \%$ & $41 \%$ \\
\hline
\end{tabular}

There were responses from staff teaching at all levels of courses, while the greatest number of respondents were teaching at BTEC [level 3] (69\%), $1^{\text {st }}$ Diploma/GCSE [level 2] (48\%), or HNC/HND $(34 \%)^{7}$. The greatest number of respondents came from the Social Sciences discipline $20 \%$. This was closely followed by Humanities 19\%, ICT 17\%, and Business $16 \%$.

\footnotetext{
${ }^{7}$ BTEC: Business and Technology Education Council (Vocational courses); GCSE: General Certificate of Secondary Education; HNC: Higher National Certificate; HND: Higher National Diploma.
} 
Overall, almost two thirds of respondents in the study (63\%) had used an e-book, and over three-quarters of these $(77 \%)$ specified they had used e-books provided by their college library. In terms of the purposes for which e-books were used, $76 \%$ indicated they used them for research, $72 \%$ for teaching, and 22\% for leisure purposes. As Table 2 below shows, respondents from 'Business, Finance and Management' and 'Social Sciences' were most likely to have used an e-book. Table 3 reveals that respondents from 'Engineering and Electronics', 'Business, Finance and Management', 'Arts and Humanities' and 'ICT' indicated a preference for e-books over their print counterparts.

Table 2: Subject area of teaching and whether respondents had ever used an e-book

\begin{tabular}{l|l|l} 
& Yes & No \\
\hline Business, Management and Finance & $79 \%$ & $21 \%$ \\
\hline Social Sciences & $74 \%$ & $26 \%$ \\
\hline Arts and Humanities & $66 \%$ & $34 \%$ \\
\hline Maths and Science & $64 \%$ & $36 \%$ \\
\hline ICT & $61 \%$ & $39 \%$ \\
\hline Hospitality and Tourism & $60 \%$ & $40 \%$ \\
\hline Engineering and Electronics & $50 \%$ & $50 \%$ \\
\hline
\end{tabular}

Table 3: Subject area of teaching and preferred format

\begin{tabular}{l|l|l} 
& E-book & Print \\
\hline Engineering and Electronics & $67 \%$ & $33 \%$ \\
\hline Business, Management and Finance & $59 \%$ & $41 \%$ \\
\hline Arts and Humanities & $58 \%$ & $42 \%$ \\
\hline ICT & $53 \%$ & $47 \%$ \\
\hline Social Sciences & $26 \%$ & $74 \%$ \\
\hline Maths and Science & $25 \%$ & $75 \%$ \\
\hline Hospitality and Tourism & $14 \%$ & $86 \%$ \\
\hline
\end{tabular}

The majority of respondents (65\%) affirmed that promotional emails from the college librarian were the most popular method of discovering and becoming aware of the e-book collection, followed by library induction $(36 \%)$. The library website $(31 \%)$ was a notable 
channel to the discovery of e-books, as it was in other studies (de Oliveira, 2012; ebrary, 2012; Jisc Collections, 2009; Muir and Hawes, 2013; Nariani, 2009), while library staff also played a significant role $(28 \%)$.

Table 4: How respondents became aware of e-books in the College Library

\begin{tabular}{l|l} 
& $\%$ of respondents \\
\hline Email notification from College Librarian & $65 \%$ \\
\hline General library induction & $36 \%$ \\
\hline College library website 'Digital Library' & $31 \%$ \\
\hline Library staff at the issue desk & $28 \%$ \\
\hline Information skills/ instruction session & $17 \%$ \\
\hline E-book induction by a Librarian & $15 \%$ \\
\hline Library catalogue & $11 \%$ \\
\hline Subject research guide & $5 \%$ \\
\hline This survey & $3 \%$ \\
\hline
\end{tabular}

This study contributes to the body of literature on the importance of library staff to the promotion and enhancement of e-books (Cassidy et al., 2012; de Oliveira, 2012; Muir and Hawes, 2013; Vasileiou et al., 2012). In fact, it is library staff that predominate the effective deployment and advancement of e-books within academic institutes (Lonsdale and Armstrong, 2010) and therefore, further marketing strategies are crucial.

A high percentage (90\%) of respondents used onsite college PCs to access e-books; faculty also accessed e-books from within their college library (29\%). A significant proportion specified they had accessed e-books from off-campus (43\%). This is consistent with the literature in that off-campus demand has increased in line with research and working patterns amongst faculty. It is expected that users in FE will change the way they access e-books due to the capability to download e-book content to computers and other mobile devices. This will provide greater flexibility as users are no longer limited to a specific platform or reader, instead a variety of devices can be used. It is clear that e-book accessibility continues to evolve and better technological options will help increase e-book demand (Herlihy and Yi, 2010; JISC, 2012; Lenares et al., 2013; Schomisch et al, 2013; Walters, 2013a,b,c). This 
survey showed that only $3 \%$ of respondents currently accessed e-books via these alternative delivery platforms; a level which will undoubtedly increase in years to come.

In terms of the amount of time FE teaching staff were spending reading e-books each week, the survey revealed that $66 \%$ of respondents spent less than one hour per week using e-books. This behaviour is prominent throughout all the literature in that academic staff prefer to browse rather that read e-books (Carlock and Perry, 2008; CIBER, 2009b; Nariani, 2009; Rowlands et al., 2007; Schomisch et al., 2013; Walton, 2007). Several other studies indicated e-books are preferred for 'brief interaction' and 'skimming' (McLure and Hoseth, 2012; Lenares et al., 2013; Schomisch et al., 2013). Most of the time pages are 'flipped' through for instant delivery (Wu and Chen, 2011, p. 301).

Table 5: Weekly time spent using e-books

\begin{tabular}{l|l} 
& $\%$ of respondents \\
\hline Less than 30 mins & $34 \%$ \\
\hline $30-60$ mins & $32 \%$ \\
\hline $1-2$ hours & $24 \%$ \\
\hline $2-5$ hours & $8 \%$ \\
\hline 5 or more hours & $2 \%$ \\
\hline
\end{tabular}

Table 6: How respondents typically used e-books

\begin{tabular}{l|l} 
& $\%$ of respondents \\
\hline Browse through chapters & $72 \%$ \\
\hline Identify key words with search tool & $56 \%$ \\
\hline Quickly scan information & $52 \%$ \\
\hline Search contents page & $51 \%$ \\
\hline Copy \& paste text into MS Word & $35 \%$ \\
\hline Print out pages to read & $26 \%$ \\
\hline Annotate useful text & $17 \%$ \\
\hline Read entire chapters & $14 \%$ \\
\hline For leisure reading & $9 \%$ \\
\hline
\end{tabular}


It has been noted that users typically interact with e-books for specific purposes (Daniel and Woody, 2013; McLure and Hoseth, 2012). This survey ascertained that, overall, e-books are used for research purposes to quickly 'browse' (72\%), 'search' (56\%) and 'scan' (52\%). This is in line with other surveys that reported reading habits were dominated by 'powerbrowsing' (Schomisch et al., 2013, p. 395). The search ability of e-books also increases their appeal and provides part of the explanation for the short reading times as users 'dip in and out' of them (Nicholas et al., 2008, p322). These patterns of use also match the previous question of quick usage sessions to browse, search and scan for appropriate information.

The innovative nature and the perceived benefits of e-books, as with other studies, is a regular theme. This study revealed that over three quarters of the academic staff respondents regarded 24/7 availability as an advantage, whilst $57 \%$ saw the search tools, and $56 \%$ saw convenience and speed, as further advantages. These findings are consistent with many other studies (ebrary, 2012; Jisc Collections, 2009; Lenares et al., 2013; McLure and Hoseth, 2012; Muir and Hawes, 2013; Walton, 2013). Remote accessibility and automatic citation were also selected. It is notable that the range of e-book selection titles scored lowest amongst all the beneficial options which ties in with some of the negative findings from this survey.

Table 7: Perceived advantages of using e-books

\begin{tabular}{l|l} 
& $\%$ of respondents \\
\hline Ease of 24/7 access & $86 \%$ \\
\hline Usefulness of search tools and other features & $57 \%$ \\
\hline Convenient / fast and easy & $56 \%$ \\
\hline Off-campus access & $47 \%$ \\
\hline Automatic references / citations & $35 \%$ \\
\hline Good range / selection of titles & $25 \%$ \\
\hline
\end{tabular}

When it came to e-book features, a number of shortcomings were identified which revealed insights into the perceived challenges of e-books. The biggest disadvantage noted from this study was the provision of relevant and current titles (55\%) and this corresponds with other studies (ebrary, 2012; Herlihy and Yi, 2010; Muir and Hawes, 2013; McLure and Hoseth, 2012; Walters, 2013a\&c). Subject appeared to be an influencing factor with regard to this 
issue, for example, $66 \%$ of engineering lecturers cited lack of relevant titles as a disadvantage as opposed to only $26 \%$ of IT lecturers.

Eye strain was also a factor with just over half of those who had used e-books voicing concern with eye discomfort (53\%). Many other studies emphasised difficulties reading online as a deterrent (de Oliveira, 2012; ebrary, 2012; Pant and Jindal, 2013; JISC, 2008; Rockinson-Szapkiw et al., 2013; Schomisch et al., 2013; Wu and Chen, 2011). This is also comparable to Abdullah and Gibb (2009), Muir and Hawes (2013) and Walters (2013b\&c) research, where their respondents indicated they found it difficult to read from the screen and were also unaware of e-book availability and titles. Interestingly, only $19 \%$ of respondents who had not used e-books cited possible eye strain a disincentive to do so. Other limitations included navigation speed and the inability to gain access from off-campus.

Table 8: Perceived disadvantages of using e-books

\begin{tabular}{l|l} 
& $\%$ of respondents \\
\hline Lack of choice of e-book titles in subject area & $55 \%$ \\
\hline Discomfort / difficulty reading from the screen & $53 \%$ \\
\hline Pages take too long to navigate / too slow & $32 \%$ \\
\hline Unable to access off-campus & $14 \%$ \\
\hline No facility to have the text read out loud & $6 \%$ \\
\hline
\end{tabular}

With regard to format preference, this study found a very slight edge for the printed format for core teaching texts (44\%), while the e-book was preferred by $41 \%$. Given that the Jisc Collections range of e-books has been available in FE Colleges since August 2009, a 41\% result reveals a strong uptake from academic staff within a period of only two years.

A significant percentage of staff in this survey indicated they encourage and include e-books in their course material $(37 \%)$, in reading lists / handouts $(39 \%)$, and in the virtual learning environment (VLE) (39\%).

Overall, faculty satisfaction levels with library e-book collections was strong with some $62 \%$ having indicated a very good or good experience. These results are consistent with other 
studies that have found a recent acceptance of e-books among academic libraries and their users, for example, (Herlihy and Yi, (2010) and Lenares et al., (2013).

Table 9: How respondents rated their overall experience of using the e-books provided by their college library

\begin{tabular}{l|l} 
& $\%$ of respondents \\
\hline Very good & $20 \%$ \\
\hline Good & $42 \%$ \\
\hline Average & $16 \%$ \\
\hline Poor & $10 \%$ \\
\hline Very poor & $4 \%$ \\
\hline N/A & $12 \%$ \\
\hline
\end{tabular}

The respondents who had never used an e-book gave their reasons for not doing so. Over half (54\%) stated lack of awareness of relevant titles in their teaching field, while $36 \%$ simply preferred print books. Difficulties with access, eyestrain and not knowing about the e-book collection were other grounds for non-usage, and this concurs with other studies such as ebrary (2012), Muir and Hawes (2013), and Walters (2013a\&c).

Table 10: Reasons respondents had not used e-books

\begin{tabular}{l|l} 
& $\%$ of respondents \\
\hline Unaware of relevant titles for their subject & $54 \%$ \\
\hline Prefer print books & $36 \%$ \\
\hline Difficulty accessing e-books & $21 \%$ \\
\hline Difficulties reading e-books from the screen & $19 \%$ \\
\hline Never knew about them & $10 \%$ \\
\hline
\end{tabular}

Respondents were also given the chance to openly give their reasons for not having used ebooks. These comments strongly correlate with the responses in Table 10 above in that the issue of not believing there were relevant titles comprised 7 of the 10 open-ended responses, although lack of time to spend on e-books was also given as a reason. Two respondents stated that further guidance from the college library on e-books would be useful.

The ten comments were: 
- Haven't made time to find out more about them;

- There are no suitable materials for the subjects I teach;

- When I last looked there wasn't anything relevant or of interest to me;

- Have not researched it properly. Need training for lecturers from library staff on specific use of e books;

- None applicable to Brickwork;

- I do not think that there are relevant texts on my subject areas;

- Never had time to look into them, would like assistance if possible;

- I doubt there is anything relevant for either ESOL or learning support literacy but would love to be proved wrong;

- Couldn't find any relevant to my area of teaching; and

- Have reviewed material range available and have found nothing useful.

When asked specifically about the issue of training in e-books from the library, almost two thirds $(65 \%)$ of those surveyed felt e-resource guidance and training from their college librarian was very important and over a quarter (28\%) stated it was fairly important. This importance of instruction from academic librarians is also reflected in a number of other studies (Briddon et al, 2009; de Oliveira, 2012; ebrary, 2007, 2012; Muir and Hawes, 2013; Nariani, 2009).

E-books will almost certainly play a bigger role in the future and it was therefore critical to ask the FE academic staff what they expected to happen in five years' time. Using both formats (print and e-book) was the most popular answer for half of those surveyed (50\%). Using e-books had a slight edge over print with (20\%) in comparison to print (19\%), with $11 \%$ answering 'Don't know'. The co-existence of print and e-formats seems likely from these results and this concurs with other findings, for example JISC (2012) and Vasileiou et al. (2012).

\section{Discussion}

It is anticipated that e-book usage in both the commercial and academic markets will continue to increase as publishers intensify the availability of e-books and students and faculty become better acquainted with e-books and mobile devices (Daniel and Woody, 2013; Lenares et al., 
2013). In fact, e-books have pressed libraries to completely re-evaluate their collection developments practices. E-books are not used in the same way as print and have not excelled in the way they were expected to. They are appreciated for their convenience, 24/7 availability and innovative features; nevertheless, users continue to indicate a preference for the printed format (Daniel and Woody, 2013; Walton, 2013). In relation to user experience, the recurrent causes for non-use of e-books are: lack of awareness, relevancy, restrictive platforms and licences, and reading from a screen (de Oliveira, 2012; ebrary, 2012; Muir and Hawes, 2013; Walters, 2013a). Although e-books in the academic arena have not been fully embraced by users, it is evident that e-books are 'not just a passing fad' (Cassidy et al. 2012, p. 328). Despite their perceived shortcomings, enthusiasm for e-books will 'prevail' (de Oliveira, 2012, p. 555). It is critical therefore to continue to examine and understand the enduser experience.

As previously mentioned, the Jisc Collections (2009) project stated e-book usage was determined according to a range of contributory factors such as age, gender, subject and academic status. Some evidence observes that e-book use varies significantly from subject to subject (Vasileiou et al., 2012). For example, the Jisc Collections project (2009) reported that Business Management titles were more popular then Engineering titles and this study also reflects a similar result. Abdullah and Gibb (2009) and Rowlands et al., (2007) state the field of 'Computer Science' has been renowned for heavy e-book usage and Levine-Clarke (2007) explains that good awareness of e-books does not always develop into higher usage rates. Yet, recent studies have found that there seems to be little deviation in e-book use by discipline (Lenares et al., 2013). It appears more research is required in this area, however, as this study also reveals, much depends on title choice and title relevance.

A quarter of lecturers from this survey $(25 \%)$ said they did not encourage or recommend the use of e-book materials. This gap should be addressed with further investigation to ensure the integration of e-books into teaching and learning practices within FE. Furthermore, attaining the interest of academic staff that have not yet used e-books will be challenging, nevertheless, if they can be shown the advantages and importantly, the tangible results, acceptance levels of e-books could improve, as faculty endorsement is fundamental (Carlock and Perry, 2008; Muir and Hawes, 2013; Vasileiou et al., 2012; Worden and Collinson, 2011). 
Dissatisfaction and non-usage of e-books are clearly linked in this survey to unawareness, accessibility and functionality issues, lack of knowledge and relevant titles (ebrary, 2012, Muir and Hawes, 2013; Pant and Jindal, 2013; Vasileiou et al., 2012; Walters, 2013a,b,c). These perceived negatives reappear often and compare with other e-book studies. They highlight the need for better support and guidance in the use of e-books, so that users have realistic expectations and can fully exploit the features that e-books can provide (de Oliveira, 2012; Muir and Hawes, 2013). As Cassidy et al. sum up, '...users naturally expect the digital environment to lend added value over a print book' (Cassidy et al., 2012, p. 329).

Uniquely, this survey revealed that $40 \%$ of the academic community in the 0-5 year teaching bracket had not used e-books (as shown in Table 1). This again highlights how crucial it is to provide new academic staff with information, direction and instructional skills on e-book collections. It is evident that library staff play a very important role and contribute to the promotion and enhancement of e-books within the colleges. It is vital that librarians continue to expose, promote and market e-books in order to develop user skills for efficient e-book utilisation (de Oliveira, 2012; ebrary, 2012; Muir and Hawes, 2013; Pant and Jindal, 2013; Vasileiou et al., 2012; Walters, 2013a). In this survey, faculty clearly valued training from library staff in relation to e-books. Libraries within the FE sector could reflect further on the current training provision for academic staff and what future training developments and support would be useful to ensure e-books are used to their full potential.

Although interaction between the two formats (print and electronic) differs, e-books play, and will continue to play, a fundamental role for academic staff. Satisfaction levels with e-books are on the whole positive. As an educational resource, e-books are valuable and have potential, but, if they are to continue to evolve, it is imperative to understand the end user's learning experience, behaviour and interaction with e-books. Appropriate titles and improved user-friendly design with consistent, standardised features across all e-book platforms are more likely to bolster e-book use in academic libraries, including those in the FE sector. One USA study asks if negative perceptions of e-books 'are affected by disparate systems?' and clearly the answer is, yes, the pessimism towards e-books is influenced by restrictive and dissimilar platforms (Walton, 2013, p. 6). The challenges and barriers associated with the development of e-books collections in academic libraries are still present and need to be addressed. E-books need to be fit for purpose. 


\section{Conclusions}

With changing user demands, it is necessary to determine usage patterns in order to make informed decisions for future e-books collections. At present, e-books complement and coexist with print collections, they have not replaced them (McClure and Hoseth, 2012; Muir and Hawes, 2013; Pan et al., 2009; Vasileiou et al., 2012; Walton, 2013). E-books will be utilised when patrons realise they are useful for their learning and research activities and will help to improve their course performance. It is crucial therefore, to continue to monitor the online behaviour of users.

The implementation and acceptance of e-books within FE has been the most striking finding of this survey. Indeed, this study provides important baseline data for future comparison, and comparison with FE institutions elsewhere. As of 2013, the majority of NI FE colleges have recorded the highest e-books usage figures throughout the UK FE sector for the Jisc 'e-books for FE project' (Jisc Collections monthly usage stats $^{8}$ ). It is clear that e-books will play an increasing role within FE. The high usage figures correspond with recent studies which point to a growing awareness and acceptance within education (Lenares et al., 2013). These figures are an encouraging result for FE colleges and reveal their commitment to e-books.

This study is pivotal to the emerging research on faculty use and perceptions of e-books in academic libraries. The unique finding, that $40 \%$ of those who had been in a teaching post for less than five years had not used an e-book, is one that requires further investigation. The study also furnishes a starting point for evaluation and assessment within FE colleges. It corroborates and compliments other recent and existing studies to highlight the end user's experience of e-books in academic settings. In a time of technological transformation, this study provides practical and timely insights into academic staff usage patterns of e-books in the FE sector, which will enable informed decisions on future e-book purchases, marketing of e-books, and the provision of related services.

\section{Acknowledgements}

\footnotetext{
${ }^{8}$ Five NI FE colleges took the top five places in the top institutional e-book users statistics relating to the Jisc 'e-books for FE project' collection, according to the Jisc Collections usage report for August 2011 to July 2012, and four NI FE colleges were placed in the top ten usage statistics for September 2012 to July 2013 (Jisc Collections 'e-books for FE project' annual usage statistics, 2012, 2013).
} 
A special thanks goes out to the all the Further Education College librarians across Northern Ireland for helping distribute the survey to their academic staff. St Mary's University College and the South Eastern Regional College must be recognised for their support for the project.

\section{References}

Abdullah, N. and Gibb, F. (2009). Students' attitudes towards e-books in a Scottish Higher Education Institute: Part 3 - search and browse tasks. Library Review, 58 (1), 17-27.

Anuradha, K. and Usha, H. (2006). Use of e-books in an academic and research environment: a case study from the Indian Institute of Science. Program: electronic library and information systems, 40 (1), 48-62.

Briddon, J., Chelin, J., Ince, G., Redman, J., Sleat, A. and Williams, E. (2009). "E-books are good if there are no copies left": a survey of e-book usage at UWE Library Services. Library and Information Research, 33 (104), 45-65.

Carlock, D. and Perry, A. (2008). Exploring faculty experiences with e-books: a focus group. Library Hi Tech, 26 (2), 244-254.

Cassidy, E., Martinez, M. and Shen, L. (2012). Not in love, or not in the know? Graduate student and faculty use (and non-use) of e-books. Journal of Academic Librarianship, 38 (6), 326-332.

CIBER (2009a). Headline Findings from the User Surveys. Retrieved March 19, 2014, from http://observatory.jiscebooks.org/reports/headline-findings-from-the-user-surveys/

CIBER (2009b). Scholarly E-books Usage and Information Seeking Behaviour: A Deep Log Analysis of MyiLibrary. Retrieved March 19, 2014, from http://observatory.jiscebooks.org/reports/scholarly-e-books-usage-and-information-seekingbehaviour-a-deep-log-analysis-of-myilibrary/ 
Daniel, D. and Woody, W. (2013). E-textbooks at what cost? Performance and use of electronic v. print texts. Computers and Education, 62, 18-23.

de Oliveira, S. (2012). E-textbooks usage by students at Andrews University: A study of attitudes, perceptions, and behaviours. Library Management, 33 (8/9), 536-560.

ebrary (2007). 2007 Global Faculty E-book Survey. Retrieved March 19, 2014, from http://www.ebrary.com/corp/collateral/en/Survey/ebrary_faculty_survey_2007.pdf

ebrary (2012). 2012 Global Student E-book Survey: United Kingdom. Retrieved March 19, 2014, from http://site.ebrary.com/lib/surveys/docDetail.action?docID=80089377

Herlihy, C. and Yi, H. (2010). E-books in academic libraries: how does currency affect usage? New Library World, 111 (9/10), 371-380.

Jamali, H., Nicholas, D. and Rowlands, I. (2009). Scholarly e-books: the views of 16,000 academics: results from the Jisc National E-Book Observatory. Aslib Proceedings, 61 (1), $33-47$.

JISC (2008). Findings from the First User Survey. Retrieved March 19, 2014, from http://observatory.jiscebooks.org/reports/findings-from-the-first-user-survey/

Jisc Collections (2009). National E-books Observatory Project: Key Findings and Recommendations. $\quad$ Retrieved March 19, 2014, from http://observatory.jiscebooks.org/reports/jisc-national-e-books-observatory-project-keyfindings-and-recommendations/

Jisc Collections (2010). Migrating to e in UK Further Education. Retrieved March 19, 2014, from http://www.jisc-collections.ac.uk/documents/migrating_to_e_in_fe_report.pdf

JISC (2012). Preparing for Effective Adoption and Use of E-books in Education (JISC Observatory TechWatch Series, Report No 4, Final version, December 2012). Retrieved March 19, 2014, from http://observatory.jisc.ac.uk/docs/ebooks-in-education.pdf 
Lenares, D., Smith, S. and Boissy, R. (2013). Ebook Use and Acceptance in an Undergraduate Institution. (Springer White Papers for Librarians, 2013). Retrieved March 19 , 2014 , from http://static.springer.com/sgw/documents/1370809/application/pdf/H6593_CB_WhitePaper_e Books_Undergraduate+Inst.pdf

Levine-Clark, M. (2007). Electronic books and the humanities: a survey at the University of Denver. Collection Building, 26 (1), 7-14.

Lonsdale, R. and Armstrong, C. (2010). Promoting your e-books: lessons from the UK JISC National e-Book Observatory. Program: electronic library and information systems, 44 (3), 185-206.

McLure, M. and Hoseth, A. (2012). Patron-driven e-book use and users' e-book perceptions: a snapshot. Collection Building, 31 (4), 136-147.

Medeiros, N. (2010). Books, books everywhere, but nary a one in print: Cushing Academy eliminates print books from its library. OCLC Systems \& Services, 26 (1), 5-7.

Muir, L. and Hawes, G. (2013). The case for e-book literacy: undergraduate students' experiences with e-books for course work. Journal of Academic Librarianship, 39 (3), 260274.

Mulholland, E. (2012). The Impact and Perceptions of E-books on Academic Staff in Further Education Colleges in Northern Ireland. Dissertation submitted for the MSc in Library and Information Management, University of Ulster.

Nariani, R. (2009). E-books in the Sciences: If we buy it will they use it? Issues in Science and Technology Librarianship, Fall 2009. Retrieved March 19, 2014, from http://www.istl.org/09-fall/article3.html 
Nicholas, A. and Lewis, J. (2010). Learning enhancement or headache: faculty and etextbooks. Faculty and Staff - Articles \& Papers. Paper 29. Retrieved March 19, 2014, from http://digitalcommons.salve.edu/fac_staff_pub/29

Nicholas, D., Rowlands, I., Clark, D., Huntington, P., Jamali, H. and Ollé, C. (2008). UK scholarly e-book usage: a landmark survey. Aslib Proceedings, 60 (4), 311-334.

O'Brien, T. (2010). E-books in Academic Libraries - A Briefing Paper. Retrieved March 19, 2014, from http://www.slideshare.net/TerryOBrien100/e-books-in-academic-libraries-abriefing-paper

Pan, R., Byrne, U. and Murphy, H. (2009). Nudging the envelope: the hard road to mainstreaming UCD Library e-book provision. Serials: The Journal for the Serials Community, 22 (3) Supplement 1, S12-S22.

Pant, A. and Jindal, S. (2013). Availability of e-books in science: case study of University of Delhi. The Electronic Library, 31 (3), 313-328.

Rockinson-Szapkiw, A., Courduff, J., Carter, K. and Bennett, D. (2013). Electronic versus traditional print textbooks: A comparison study on the influence of university students' learning. Computers and Education, 63, 259-266.

Roesnita, I. and Zainab, A. (2005). The pattern of e-book use amongst undergraduates in Malaysia: a case of to know is to use. Malaysian Journal of Library and Information Science, 10 (2), 1-23. Retrieved March 14, 2014, from http://arxiv.org/ftp/arxiv/papers/1301/1301.5400.pdf

Rowlands, I., Nicholas, D., Jamali, H. and Huntington, P. (2007). What do faculty and students really think about e-books? Aslib Proceedings, 59 (6), 489-511.

Schomisch, S., Zens, M. and Mayr, P. (2013). Are e-readers suitable tools for scholarly work? Results from a user test. Online Information Review, 37 (3), 388-404. 
Shelburne, W. (2009). E-book usage in an academic library: user attitudes and behaviors. Library Collections, Acquisitions, and Technical Services, 33 (2/3), 59-72.

Springer (2010). A Survey of E-book Usage and Perceptions at the University of Liverpool: University of Liverpool E-book Study: Part 2. Retrieved March 19, 2014, from http://static.springer.com/sgw/documents/1343310/application/pdf/V7671_Liverpool_White_ Paper_Part2\%5B1\%5D.pdf

Smyth, S. and Carlin A. (2012). Use and perception of e-books in the University of Ulster: A case study. New Review of Academic Librarianship, 18 (2), 176-205.

Soules, A. (2009). The shifting landscapes of e-books. New Library World, 110 (1/2), 7-21.

Tonkin, E. (2010). Ebooks: Tipping or Vanishing Point? Ariadne, 62. Retrieved March 19, 2014, from http://www.ariadne.ac.uk/issue62/tonkin

Tucker, J. (2012). Ebook collection analysis: subject and publisher trends. Collection Building, 31 (2), 40-48.

Vasileiou, M., Hartley, R. and Rowley, J. (2012). Perspectives on the future of e-books in libraries in universities. Journal of Librarianship and Information Science, 44 (4), 217-226.

Walters, W. (2013a). E-books in academic libraries: challenges for acquisition and collection management. Libraries and the Academy, 13 (2), 187-211.

Walters, W. (2013b). E-books in academic libraries: challenges for sharing and use. Journal of Librarianship and Information Science, published online 10 January 2013. Retrieved March 19, 2014, from http://lis.sagepub.com/content/early/2013/05/08/0961000612470279

Walters, W. (2013c). E-books in academic libraries: challenges for discovery and access. Serials Review, 39, 97-104.

Walton, E. (2007). Faculty and student perceptions of using e-books in a small academic institution. ACRL Thirteenth National Conference, March 29-April 1, 2007, Baltimore, 
Maryland. $\quad$ Retrieved $\quad$ March $\quad 19, \quad$ 2014, from http://www.ala.org/acrl/sites/ala.org.acrl/files/content/conferences/confsandpreconfs/national/ baltimore/papers/92.pdf

Walton, E. (2013). Why undergraduate students choose to use e-books. Journal of Librarianship and Information Science, published online 21 May 2013. Retrieved March 19, 2014, from http://lis.sagepub.com/content/early/2013/05/19/0961000613488124

Worden, A. and Collinson, T. (2011). Engaging staff and students with e-books in a university setting. In: Price, $\mathrm{K}$ and Havergal, V (eds) E-books in Libraries: A Practical Guide. London: Facet, 237-251.

Wu, M. and Chen, S. (2011). Graduate students' usage of and attitudes towards e-books: experiences from Taiwan. Program: electronic library and information systems, 45 (3), 294307. 


\section{Appendix}

Survey: The Impact and Perceptions of E-books on Academic Staff in Further Education Colleges, N. Ireland

1. Please state your faculty status: Full time / Part time

2. Please state your gender: Male / Female

3. How many years have you been teaching? 0-5 / 6-10/ 11-15 / 16-20 / 20+

4. What is the level of the course you teach? (please tick all that apply)

$1^{\text {st }}$ Diploma/GCSE [Level 2] / BTEC National [Level 3] / AS/A Levels / Apprenticeship Course NI / HNC/HND / Foundation Degree / Degree [Level 6 and above] / Professional Course [Level 5 and above]

5. Which of the following subject areas best describes your area of teaching?

Arts and Humanities / Business, Finance and Management / Engineering and Electronics / Hospitality and Tourism / Maths and Science / Social Sciences / ICT

6. Have you ever used an e-book? If yes, please proceed to Q7. If no, please proceed to Q21. Yes / No

7. For what purposes do you usually use e-books? (please tick all that apply) Teaching / Research / Leisure

8. How did you find out about e-books that available in your college library? (please tick all that apply)

General library induction / Email notification from your college librarian / Library staff at the issue desk / This survey / Through an information skills/Library instructional session on e-resources (including e-books) / Subject research guide / Library college website 'Digital Library' / Library catalogue / Through an e-books induction by a librarian

9. Have you used the e-books that are available from your College Library? If yes, please proceed to Q10. If no, please proceed to Q14. Yes / No

10. How have you accessed e-books that are available from your College Library? (please tick all that apply)

From a computer in my college / From a computer in my college library / From home/off campus / From a portable mobile device

11. In a week, how long do you usually spend on e-books?

10+ hrs / 5-10 hrs / 2-5 hrs / 1-2 hrs / 30 mins-1 hr / less than 30 mins

12. In a typical session, how long do you spend reading an e-book from the screen?

20 mins + / 11-20 mins / 6-10 mins / 3-5 mins / less than 3 mins

13. How do you normally use e-books? (please tick all that apply)

Browse through the chapters / Read entire chapters / Use the search tools to identify key words within the books / Scan information quickly / Search through the contents page / Annotate text that was useful / Copy and paste text into Microsoft Word or other computer software / Print out pages to read in print / For leisure reading

14. On a scale of 1-5 (1=lowest, $5=$ highest), how much do you depend on e-books for your teaching/research? $1 / 2 / 3 / 4 / 5$

15. What are the advantages of using e-books? (please tick all that apply)

Ease of access - ability to access books anytime (24/7), anywhere / Usefulness of search tools and other available features / Automatic referencing/citations / Off campus access (remote access) / Convenient/fast and easy / Good range/selection of titles 
16. What are the disadvantages of using e-books? (please tick all that apply)

Discomfort/difficulty reading from the screen / Lack of choice of e-book titles for the subject areas relevant to my teaching area / Could not gain access off-campus / Pages take too long to navigate/too slow / No facility to have the text read out loud

17. Thinking about the core texts required for teaching your course(s), would you prefer to use an e-book or a printed book? E-book / Printed book / Don't know

18. In response to Q17, please use the space below to explain why you would prefer to use either an e-book or a printed book.

19. Do you recommend or actively encourage your students to use e-book materials? (please tick all that apply) Yes, e-books are included in a VLE / Yes, e-books are on my reading list or handouts / Yes, e-books are included as course material / No

20. How would you rate your overall experience of using the e-books provided by your College Library?

Very good / Good / Average / Poor / Very poor / N/A

21. Only answer this question if you answer No to Q6. Why have you not used e-books? (please tick all that apply)

Never knew about them / I prefer to use printed books / Had difficulty accessing them/couldn't find them / I find it difficult to read e-books from the screen / I was unaware of relevant titles for the subject I teach

22. How important do you feel instruction/training by a librarian is on the use of electronic resources to your work? Very important / Fairly important / Not important

23. What do you expect to happen with e-books in 5 years' time?

For some books, I will prefer to read print books, for others I will prefer the e-book / I will mostly read print books / I will mostly read e-books / Don't know

24. At which Further Education College in Northern Ireland do you teach?

Belfast Metropolitan College / Northern Regional College / North West Regional College / South Eastern Regional College / Southern Regional College / South West College

25. Please add any other comments you might have in relation to e-books. 